\section{Sociodemographic profile of primiparous mothers from nine birth cohorts in three Brazilian cities}

\author{
Perfil sociodemográfico de mulheres primíparas \\ de nove coortes de nascimentos em três \\ cidades brasileiras
}

\section{Perfil sociodemográfico de mujeres madres primíparas de nueve cohortes de nacimiento en tres ciudades brasileñas}

Simone Farias-Antunez 1

Vanda Maria Ferreira Simões 2

Viviane Cunha Cardoso 3

Mariângela Freitas da Silveira 1

doi: 10.1590/0102-311X00057520

\begin{abstract}
Fertility reduction is a phenomenon observed in demographic transition. The demographic changes noted in female fertility represent a need for adjustment on health services regarding female health and family planning support. Thus, this study aimed to perform a descriptive analysis by tracing the sociodemographic profile of primiparous mothers belonging to nine Brazilian birth cohorts, in three cities from different states. Standardized questionnaires were applied to assess reproductive characteristics and covariables. Primiparous mothers were defined as women whose child included in birth cohorts was their firstborn child. Sample description was performed using analysis of variance (continuous variables) and chi-square (categorical variables). In

\author{
Correspondence \\ S. Farias-Antunez \\ Programa de Pós-graduação em Epidemiologia, Universidade \\ Federal de Pelotas. \\ Av. Marechal Deodoro 1160, 4o andar, Pelotas, RS \\ 96020-080, Brasil. \\ simonefarias47@gmail.com \\ 1 Programa de Pós-graduação em Epidemiologia, Universidade \\ Federal de Pelotas, Pelotas, Brasil. \\ 2 Departamento de Saúde Pública, Universidade Federal do \\ Maranhão, São Luís, Brasil. \\ 3 Faculdade de Medicina de Ribeirão Preto, Universidade de São \\ Paulo, Ribeirão Preto, Brasil.
} total, 44,615 women were included in the analyses and 41.8\% (95\% CI: 41.3; 42.2) were categorized as primiparous. The primiparity rates were the lowest in Ribeirão Preto (São Paulo State) 1978 (32\%; 95\%CI: 30.9; 33.1) and the highest in most recent cohorts, reaching up to $50 \%$ of the participants (São Luís - Maranhão State 2010: 47.2\%; 95\%CI: 45.8; 48.6; Ribeirão Preto 2010: 50.2\%; 95\%CI: 49.1; 51.4); Pelotas (Rio Grande do Sul State) 2015: 49.4\% (95\%CI: 47.9; 50.9). Primiparous mothers' age and schooling increased over the years in all cohorts. Maternal age at the first childbirth behaved similarly in the three studied cities. There was an increase in the proportion of firsttime mothers that were older, higher educated and belonged to richer income groups. Also, the proportion of teenage mothers (aged 15 years or younger) increased until the early 2000's and started decreasing around the years 2010, especially among women in the poorer income groups.

Parity; Pregnancy; Pregnancy in Adolescence; Socioeconomic Factors 


\section{Introduction}

The reduction of fertility is one of the transformations observed in demographic transition - along with mortality reduction and changes in morbidity patterns (from infectious to chronic diseases). This phenomenon has developed over the last 150 years, incurring changes in the population's structure with an increase in the absolute number of older adults as well as in the proportion of older adults over children in the population 1 . Women no longer reach an average of six or seven childbirths but rather less than two in most economically advanced countries (The World Bank. Fertility rate, total (births per woman), 2018. https://data.worldbank.org/indicator/SP.DYN.TFRT.IN, accessed on Mar/2020).

In Brazil, fertility control was a heterogeneous event first observed, in the early 1940s, among the richer and higher educated women from urban areas in the country's most developed region (Southeast). The North and Northeast regions showed a noted decrease in fertility 20 years later, being this difference observed not exclusively in some regions but also among rural and urban areas 2 . These regional differences can still be observed. When compared to women living in the North, women from more developed regions show lower fertility levels, being the fertility profile influenced by education, socioeconomic status, age, macro-region, marital status, age of first sexual intercourse, and age at first birth 3 .

Since the mid-2000s, fertility rates in Brazil have been below the replacement level. This, along with an increase in the mean age of fertility between 2000 and 2010, suggests that a fall in fertility levels in the country could have been intensified by the postponement of births 4 . Postponing the first pregnancy could also result in a larger proportion of women reaching the end of the reproductive period without or with fewer children than planned.

Although an increase in the proportion of women aged over 30 years giving birth has been observed, the persistence of deliveries from girls aged under 15 years is still noted, representing $0.7 \%$ of total births, reaching up to $3.7 \%$ among indigenous women (Brazilian Health Informatics Department. http://www2.datasus.gov.br/DATASUS/index.php?area $=0205 \&$ id=6936, accessed on $30 / \mathrm{Sep} / 2020$ ). An increasing tendency of unwanted pregnancies is also observed. Approximately three-quarters of pregnancies of single women aged from 15 to 19 years are unwanted 5 . In addition to the social, economic, and family constraints this entails, many of these pregnancies are interrupted by unsafe abortion, a major cause of maternal mortality and morbidity 6 .

Primiparous mothers' sociodemographic and health characteristics are especially relevant since first-time pregnancies are associated with a three times higher risk of pre-eclampsia 7 along with other complications during pregnancy and childbirth such as prolonged labor 8,9, and emergency cesarean section 8,10 . Advanced maternal age - shown to be negatively associated with fecundability and the ability to conceive 11 - also increases the risk of developing hypertension-related disorders during pregnancy $12,13,14$.

The changing scenario in childbearing will result in new demands to be met in healthcare services, including pregnancy and further family planning assistance. Considering this, this study aimed to perform a descriptive analysis by tracing the sociodemographic profile of primiparous mothers belonging to nine Brazilian birth cohorts, dating from 1978 to 2015 (1978, 1982, 1993, 1994, 1997, 2004, 2010, and 2015), in three different cities from three states.

\section{Methodology}

This was a cross-sectional population-based study using data from nine Brazilian birth cohorts conducted between 1978 and 2015 in the cities of Ribeirão Preto (São Paulo State), Pelotas (Rio Grande do Sul State), and São Luís (Maranhão State).

Ribeirão Preto is located in Southeast Brazil, in the State of São Paulo, and this city has a population of approximately 590,593. It has a high Human Development Index (HDI), 0.800 (as of 2010). Three birth cohorts were implemented in the city of Ribeirão Preto in the years 1978/1979, 1994, and 2010. From June 1, 1978, to May 31, 1979, 6,973 live births occurring in eight hospitals in the region were included in the study, representing $98 \%$ of those born in this period. In 1994, all live births between April 25 and August 25 in all maternity hospitals in the city were eligible for the study, totaling 2,846 
individuals. A third birth cohort was developed in the city in 2010 as part of the BRISA (Brazilian Birth Cohort Studies - Ribeirão Preto-São Luís) multicenter study in Ribeirão Preto and São Luís, including all births from January 1 to December 31, 2010 and enrolling 7,794 children in Ribeirão Preto. Detailed information on the methodology of the Ribeirão Preto cohorts have been published elsewhere 15,16,17.

Pelotas is a city with approximately 350,000 inhabitants located in Rio Grande do Sul, the Southernmost state of Brazil. In 2010, its HDI was 0.739. In the years 1982, 1993, 2004, and 2015, all live births from January 1 to December 31, to mothers that lived within the urban area of Pelotas and in the Jardim América district (which currently belongs to the neighboring municipality of Capão do Leão), were deemed eligible for the study. The total number of participants was 5,914 in 1982, 5,265 in 1993, 4,287 in 2004, and 4,275 in 2015, representing 98.4\%, 99.1\%, 99.2\%, and 97.2\% of the city births, respectively. More information on the Pelotas birth cohort methodology has been described previously 18,19,20,21.

The city of São Luís is the capital of the state of Maranhão and it is located in the Northeast region, one of the poorest states in Brazil. With a population of 958,545, the HDI of São Luís in 2010 was 0.768. Two birth cohorts were initiated in the city. The first included all births that occurred in the city maternity wards from March 1, 1997 to February 28, 1998, totaling 2,831 eligible children with a response rate of $96.3 \%$. The second cohort was part of the BRISA study and evaluated all live births from January 1 to December 31, 2010. One-third of all 21,401 live births in this period were systematically sampled into the study. A total of 5,212 individuals were included, comprising $95.4 \%$ of all eligible births. Details of the São Luis cohort methodology can be found in previous publications 22,23.

The BRISA study was developed in 2010 aiming to analyze perinatal outcomes, sociodemographic and behavioral factors, and use of health and perinatal services in a new birth cohort in the cities of Ribeirão Preto and São Luís and to compare these indicators to those from the previous cohorts in each site 22. In 2018, Pelotas joined Ribeirão Preto and São Luís in a project intended to bring the three centers that manage the oldest and largest birth cohorts in Brazil (Ribeirão Preto, Pelotas, and São Luís) together to coordinate efforts (Figure 1).

All cohorts included in this study applied standardized questionnaires to assess socioeconomic, demographic, reproductive, and behavioral information.

Primiparous mothers were defined as women whose pregnancy to the child included in any birth cohorts was their first. Only singleton births were included in the analysis.

This study included the following maternal characteristics as covariates: age (years), schooling (years), marital status (with or without a partner), skin color (white or other), and family income (quin-

\section{Figure 1}

Brazilian births cohorts included in the study.

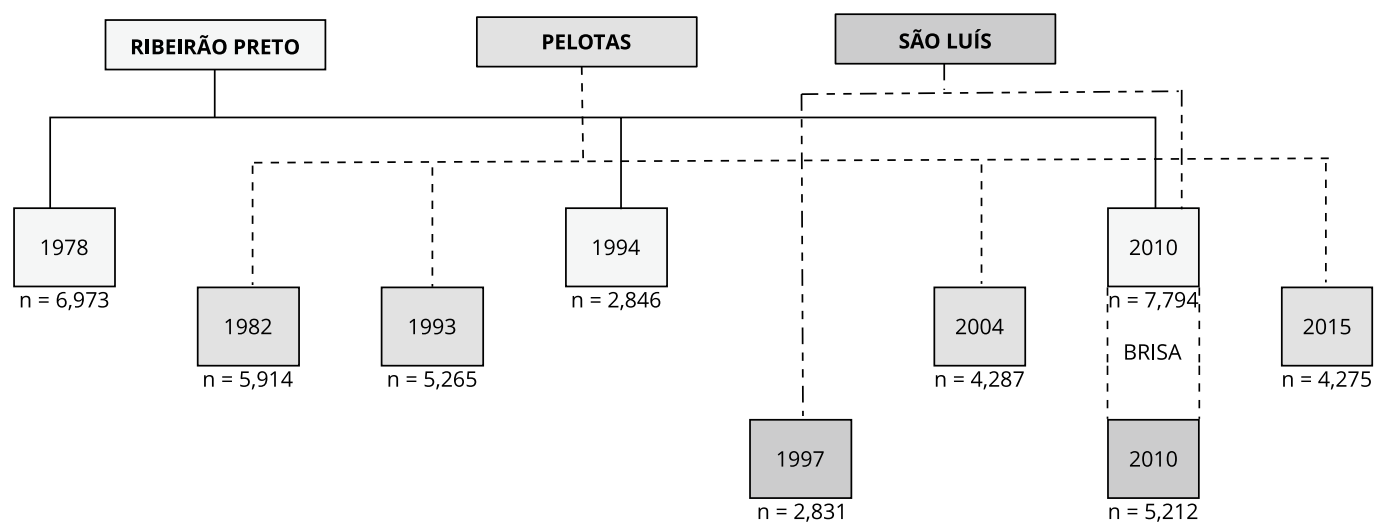

BRISA: Brazilian Birth Cohort Studies - Ribeirão Preto-São Luís. 
tiles). All cohorts collected maternal date of birth on the perinatal interviews enabling the estimation of maternal age at childbirth. Maternal schooling and, dwelling with or without a partner were collected with maternal self-report in all cohorts. The interviewed mothers answered questions about the latest grade they completed at school and this information was converted into years, considering the organization of the Brazilian schooling system. The mothers were also questioned about their relationship status (single, married, divorced, widowed, or living with a partner). These answers were categorized into living with (married or living with a partner) or without (single, divorced, widowed) a partner. Skin color was collected by the interviewer's perception in Pelotas 1982 and 1993, and Ribeirão Preto 1978, and maternal self-report in Pelotas 2004 and 2015, and 2010 BRISA Cohorts (Ribeirão Preto and São Luís). Also, the participants answered about family income, including the income anyone that lived in the household had received in the month preceding the interview.

A sample description according to the cohort of origin and socio-demographic characteristics was carried out using analysis of variance (continuous variables) and chi-square (categorical variables). Also, the frequency of primiparity and its respective confidence intervals in each cohort were described - considering a significance level of 0.05 . Chi-square analysis and analysis of variance were used to describe the primiparous mothers belonging to each birth cohort. Furthermore, a detailed description of the primiparas according to the mother's age and family income in the perinatal period was performed.

Statistical analyses were performed using the Stata version 16 (https://www.stata.com/).

The cohorts included in this study were approved by the Ethics Research Committees of the Universities at each city, associated with the National Research Ethics Committee (CONEP, in Portuguese). Written informed consent form was obtained from all subjects.

\section{Results}

In total, 44,615 mother/child dyads were included in this study. In Ribeirão Preto, there were 6,827 in 1978, 2,846 in 1994, and 7,606 in 2010. The city of Pelotas had 5,816 dyads in its 1982 birth cohort, 5,168 in its 1993 cohort, 4,145 in its 2004 cohort, and 4,164 in its 2015 cohort. São Luís cohorts had 2,831 participants enrolled in the year of 1997, and 5,212 in 2010.

The average age of mothers included from all cities was 26.0 (SD: 6.9) years; for São Luís (1997), Pelotas (2015), and Ribeirão Preto (2010) the averages were 23.0 (SD: 5.5), 27.6 (SD: 6.6) and 27.0 (SD: 6.3) years, respectively. Mothers from Ribeirão Preto in 1994 had, on average, the lowest levels of schooling (4.3 years, SD: 2.5), while those who belonged to Pelotas (2015), Ribeirão Preto (2010), and São Luís (2010) presented the highest schooling levels, with approximately 10 years of formal schooling (Pelotas: 10.0, SD: 4.0; Ribeirão Preto: 10.3, SD: 3.1; and São Luís: 10.0, SD: 2.8). About 80\% (79.7\%; 95\%CI: 79.3; 80.0) of women included in the cohort were married or living with a partner. The lowest prevalence was observed in São Luís in 1997 and 2010, with 75.6\% (95\%CI: 74.0; 77.2) and $77.6 \%(95 \% \mathrm{CI}: 76.5 ; 78.8)$ of mothers living with a partner. The highest prevalence was observed in Ribeirão Preto in 1978 (92\%; 95\%CI: 91.4; 92.7) and in Pelotas in 1982 (91.8\%; 95\%CI: 91.1; 92.5). A total of 62.5\% (95\%CI: 62.0; 63.1) of women self-reported as being white. In São Luís (2010), 18.4\% (95\%CI: 17.4; 19.5) of the included mothers considered their skin color as white, while in Pelotas in 1982, 82.1\% (95\%CI: 81.1; 83.0) of the study's population was white (Table 1).

From the $81.1 \%$ (95\%CI: 80.5; 82.6) of women that were classified as being non-white in São Luís (2010), 12.9\% (95\%CI: 12.1; 13.9) self-reported being black, 67.2\% (95\%CI: 65.9; 68.4) being brown, and less than $2 \%(1.4 \% ; 95 \%$ CI: $1.1 ; 1.8)$ classified them-selves as yellow or indigenous. In the same year, $41.6 \%$ (95\%CI: 40.5; 42.7) of mothers from Ribeirão Preto (2010) were categorized as black/ brown/other being 9.6\% (95\%CI: 8.9; 10.3) of them black, 31.2\% (95\%CI: 30.1; 32.2) brown, and less than $1 \%(0.8 \%$; $95 \%$ CI: $0.6 ; 1.0)$ yellow or indigenous (data not shown in tables).

Out of the 44,615 mothers included in the study, $41.8 \%$ (95\%CI: 41.3; 42.2) were delivering their firstborn child, being categorized as primiparous for this study. The primiparity rates were lowest in Ribeirão Preto in 1978 (32\%; 95\%CI: 30.9; 33.1) and most recent cohorts presented the highest rate, reaching up to 50\% of participants (São Luís 2010: 47.2\%, 95\%CI: 45.8; 48.6; Ribeirão Preto 2010: 50.2\%, 95\%CI: 49.1; 51.4; Pelotas 2015: 49.4\%, 95\%CI: 47.9; 50.9). Note that in the city of São Luís, 
Table 1

Sociodemographic characteristics of the study population according to the nine birth cohorts.

\begin{tabular}{|c|c|c|c|c|c|}
\hline \multirow[t]{2}{*}{ Cohort } & \multirow[t]{2}{*}{$\mathbf{n}$} & \multirow{2}{*}{$\begin{array}{l}\text { Age (years) } \\
\text { SD }\end{array}$} & \multirow{2}{*}{$\begin{array}{c}\text { Schooling (years) } \\
\text { SD }\end{array}$} & \multirow{2}{*}{$\begin{array}{l}\text { Marital status (living } \\
\text { with partner) } \\
\%(95 \% \mathrm{Cl})\end{array}$} & \multirow{2}{*}{$\begin{array}{l}\text { Skin color (white) } \\
\qquad \%(95 \% \mathrm{Cl})\end{array}$} \\
\hline & & & & & \\
\hline \multicolumn{6}{|c|}{ Ribeirão Preto } \\
\hline 1978 & 6,827 & $26.4(9.1)$ & $6.0(4.0)$ & $92.0(91.4 ; 92.7)$ & $69.7(67.6 ; 71.6)$ \\
\hline 1994 & 2,846 & $25.7(6.1)$ & $4.3(2.5)$ & $87.3(86.0 ; 88.5)$ & NA \\
\hline 2010 & 7,606 & $27.0(6.3)$ & $10.3(3.1)$ & $86.4(85.6 ; 87.2)$ & $58.4(57.3 ; 59.5)$ \\
\hline \multicolumn{6}{|l|}{ Pelotas } \\
\hline 1982 & 5,816 & $25.8(6.1)$ & $6.5(4.2)$ & $91.8(91.1 ; 92.5)$ & $82.1(81.1 ; 83.0)$ \\
\hline 1993 & 5,168 & $26.0(6.4)$ & 6.7 (3.6) & $87.6(86.7 ; 88.5)$ & $77.3(76.2 ; 78.5)$ \\
\hline 2004 & 4,145 & $26.1(6.8)$ & $8.1(3.5)$ & $83.7(82.5 ; 84.8)$ & $68.1(66.6 ; 69.6)$ \\
\hline 2015 & 4,164 & $27.6(6.6)$ & $10.0(4.0)$ & $85.8(84.7 ; 86.8)$ & $70.6(69.2 ; 72.0)$ \\
\hline \multicolumn{6}{|l|}{ São Luís } \\
\hline 1997 & 2,831 & $23.0(5.5)$ & $7.5(3.5)$ & $75.6(74.0 ; 77.2)$ & NA \\
\hline 2010 & 5,212 & $25.2(6.0)$ & $10.0(2.8)$ & $77.6(76.5 ; 78.8)$ & $18.4(17.4 ; 19.5)$ \\
\hline Total & 44,615 & $26.0(6.9)$ & $7.9(4.0)$ & $79.7(79.3 ; 80.0)$ & $62.5(62.0 ; 63.1)$ \\
\hline
\end{tabular}

95\%Cl: 95\% confidence interval; NA: not available; SD: standard deviation.

primiparity rates were consistently high between the two cohorts (1997: 47.8\%, 95\%CI: 46.0; 49.6; 2010: 47.2\%, 95\%CI: 45.8; 48.6) (Table 2).

In the earlier cohorts, women's mean age was approximately 22 years (Ribeirão Preto 1978: 22.4 years, SD: 4.9; Pelotas 1982: 22.5 years, SD: 5.0), and in the more recent cohorts, average age was 25 years (Ribeirão Preto 2010: 25.1 years, SD: 6.2; Pelotas 2015: 25.1 years, SD: 6.2). Average years of formal education varied from 7 to 11 among mothers from these two cities (Ribeirão Preto 1978: 7.3 years, SD: 4.0; Ribeirão Preto 2010: 11.1 years, SD: 2.8; Pelotas 1982: 7.3 years, SD: 4.1; Pelotas 2015: 10.8 years, SD: 3.8). In São Luís, although maternal mean age (São Luís 1997: 21.0 years, SD: 4.7; São Luís 2010: 23.2 years, SD: 5.7) and average schooling years (São Luís 1997: 8.2 years, SD: 3.1; São Luís 2010: 10.6 years, SD: 2.5) varied, the difference between the two periods is smaller than in the other two cities. In Pelotas, the proportion of primiparous mothers living with a partner at the time of childbirth decreased from 1982 to 2004 (1982: 86.4\%, 95\%CI: 85.0; 87.8; 1993: 78.9\%, 95\%CI: 77.0; 80.7; 2004: 76.6, 95\%CI: 74.5; 78.6) and displayed an increase in 2015 (84.4\%, 95\%CI: 82.8; 85.9). In Ribeirão Preto, a similar pattern was observed, decreasing from 1978 to 1994 and increasing in 2010 (1978: 87.5, 95\%CI: 86.0; 88.8; 1994: 79.6\%, 95\%CI: 77.1; 82.1; 2010: 84.3, 95\%CI: 83.1; 85.4), whereas in São Luís the opposite pattern was observed, with an increase in women who reported being married or living with a partner (1997: 69.7\%, 95\%CI: 67.2; 72.1; 2010: 77.4\%, 95\%CI: 75.7; 79.0). Mothers having their first child and who belonged to the lowest income quintile were less prevalent over the years in Ribeirão Preto and Pelotas. São Luís showed no difference in the primiparous samples regarding income $(\mathrm{p}=0.093)$. A similar pattern was observed in primiparous women's skin color in Ribeirão Preto and Pelotas (Table 3).

Maternal age at first childbirth exhibited similar trends in the three studied cities. The proportion of younger mothers - those aged 15 years or younger and from 16 to 19 years old at childbirth - increased until the early 2000s and started decreasing during the 2010s (Pelotas' mothers aged 15 years old or younger; 1982: 2.6\%, 95\%CI: 2.0; 3.3; 1993: 5.6\%, 95\%CI: 4.6; 6.7; 2004: 6.5\%, 95\%CI: 5.4; 7.7; 2015: 3.3\%, 95\%CI: 2.6; 4.2). The oldest age groups showed a linear increase over the years in Ribeirão Preto (30-34 years and 35 years or older) and Pelotas (30-34 years old). In Ribeirão Preto 2010 and Pelotas 2015, approximately 18\% of the primiparous mothers were aged from 30-34 years, whereas in São Luís 2010 only 10.9\% (95\%CI: 9.7; 12.2) of mothers were in this age group. The same 
Table 2

Distribution of primiparous mothers in the nine birth cohorts.

\begin{tabular}{ccc}
\hline Cohort & $\mathbf{n}$ & $\%(95 \% \mathrm{Cl})$ \\
\hline $\begin{array}{c}\text { Ribeirão Preto } \\
1978\end{array}$ & 2,182 & \\
1994 & 1,040 & $32.0(30.9 ; 33.1)$ \\
2010 & 3,760 & $36.8(35.0 ; 38.6)$ \\
Pelotas & & $49.8(48.6 ; 50.9)$ \\
1982 & 2,299 & \\
1993 & 1,826 & $39.5(38.3 ; 40.8)$ \\
2004 & 1,643 & $35.3(34.0 ; 36.6)$ \\
2015 & 2,056 & $39.7(38.2 ; 41.1)$ \\
São Luís & & $49.4(47.9 ; 50.9)$ \\
1997 & 1,353 & \\
2010 & 2,460 & $47.8(46.0 ; 49.6)$ \\
Total & 18,619 & $47.2(45.8 ; 48.6)$ \\
\hline
\end{tabular}

95\%Cl: 95\% confidence interval.

Table 3

Primiparous mothers' description, according to sociodemographic characteristics, in each cohort.

\begin{tabular}{|c|c|c|c|c|c|}
\hline \multirow[t]{2}{*}{ Cohort } & Age (years) & Schooling (years) & $\begin{array}{c}\text { Marital status } \\
\text { (living with partner) }\end{array}$ & $\begin{array}{l}\text { Income (poorer- } \\
\text { quintil) }\end{array}$ & Skin color (white) \\
\hline & SD & SD & $\%(95 \% \mathrm{Cl})$ & $\%(95 \% \mathrm{Cl})$ & $\%(95 \% \mathrm{Cl})$ \\
\hline Ribeirão Preto & $p<0.001$ & $p<0.001$ & $p<0.001$ & $p<0.001$ & $p<0.001$ \\
\hline 1978 & $22.4(4.9)$ & $7.3(4.0)$ & $87.5(86.0 ; 88.8)$ & $18.8(17.0 ; 20.7)$ & $70.2(66.7 ; 73.5)$ \\
\hline 1994 & $22.6(5.4)$ & $4.7(2.3)$ & $79.6(77.1 ; 82.1)$ & $17.1(14.8 ; 19.4)$ & - \\
\hline 2010 & $25.1(6.2)$ & $11.1(2.8)$ & $84.3(83.1 ; 85.4)$ & $16.5(15.3 ; 17.7)$ & $62.4(60.9 ; 64.0)$ \\
\hline Pelotas & $p<0.001$ & $p<0.001$ & $p<0.001$ & $p<0.001$ & $p<0.001$ \\
\hline 1982 & $22.5(5.0)$ & $7.3(4.1)$ & $86.4(85.0 ; 87.8)$ & $21.3(19.7 ; 23.1)$ & $84.3(82.7 ; 85.7)$ \\
\hline 1993 & $22.2(5.4)$ & $7.5(3.5)$ & $78.9(77.0 ; 80.7)$ & $17.0(15.3 ; 18.8)$ & $80.3(78.4 ; 82.0)$ \\
\hline 2004 & $22.4(5.7)$ & $9.1(3.2)$ & $76.6(74.5 ; 78.6)$ & $19.7(17.9 ; 21.7)$ & $71.2(68.9 ; 73.4)$ \\
\hline 2015 & $25.1(6.2)$ & $10.8(3.8)$ & $84.4(82.8 ; 85.9)$ & $17.9(16.3 ; 19.6)$ & $72.1(70.2 ; 74.0)$ \\
\hline São Luís & $p<0.001$ & $p<0.001$ & $p<0.001$ & $p=0.093$ & - \\
\hline 1997 & $21.0(4.7)$ & $8.2(3.1)$ & $69.7(67.2 ; 72.1)$ & $17.9(15.8 ; 19.9)$ & - \\
\hline 2010 & $23.2(5.7)$ & $10.6(2.5)$ & $77.4(75.7 ; 79.0)$ & $18.7(17.2 ; 20.3)$ & $20.1(18.6 ; 21.8)$ \\
\hline Total & $23.2(5.7)$ & $9.0(3.8)$ & 74.2 (73.6; 74.9) & $18.3(17.7 ; 18.8)$ & $63.7(62.9 ; 64.4)$ \\
\hline
\end{tabular}

95\% Cl: 95\% confidence interval; SD: standard deviation.

could be observed in the group of mothers aged 35 years or older at childbirth, approximately $7 \%$ in the former two cities and 4\% in São Luís, in the same period (Table 4).

When describing primiparous aged 15 or younger and 35 or older according to family income, in the cities of Pelotas and Ribeirão Preto, the poorer income quintile showed an expressive decrease in the 1990s followed by a progressive increase of young mothers in the late 2000s and 2010s. A similar pattern can be observed in Ribeirão Preto for the second poorer income quintile but not in Pelotas. For the richer income quintile, the proportion of mothers that were aged 15 years or younger behaved similarly to the poorer quintile, a decrease followed by an increase in later years can be observed. 
Primiparous mothers' description according to age groups in each cohort.

\begin{tabular}{|c|c|c|c|c|c|c|c|c|c|c|c|c|}
\hline \multirow[t]{3}{*}{ Cohorts } & \multicolumn{12}{|c|}{ Age (years) } \\
\hline & \multicolumn{2}{|r|}{$\leq 15$} & \multicolumn{2}{|r|}{$16-19$} & \multicolumn{2}{|r|}{$20-24$} & \multicolumn{2}{|r|}{$25-29$} & \multicolumn{2}{|r|}{$29-34$} & \multicolumn{2}{|r|}{$\geq 35$} \\
\hline & $\mathbf{n}$ & $\begin{array}{c}\% \\
(95 \% \mathrm{Cl})\end{array}$ & $\mathbf{n}$ & $\begin{array}{c}\% \\
(95 \% \mathrm{Cl})\end{array}$ & $\mathbf{n}$ & $\begin{array}{c}\% \\
(95 \% \mathrm{Cl})\end{array}$ & $\mathbf{n}$ & $\begin{array}{c}\% \\
(95 \% \mathrm{Cl})\end{array}$ & $\mathbf{n}$ & $\begin{array}{c}\% \\
(95 \% \mathrm{Cl})\end{array}$ & $\mathbf{n}$ & $\begin{array}{c}\% \\
(95 \% \mathrm{Cl})\end{array}$ \\
\hline \multicolumn{13}{|c|}{ Ribeirão Preto } \\
\hline 1978 & 48 & $\begin{array}{c}2.2 \\
(1.7 ; 2.9)\end{array}$ & 588 & $\begin{array}{c}27.0 \\
(25.1 ; 28.8)\end{array}$ & 928 & $\begin{array}{c}42.5 \\
(40.5 ; 44.6)\end{array}$ & 459 & $\begin{array}{c}21.0 \\
(19.4 ; 22.8)\end{array}$ & 129 & $\begin{array}{c}5.9 \\
(5.0 ; 7.0)\end{array}$ & 30 & $\begin{array}{c}1.4 \\
(0.9 ; 1.9)\end{array}$ \\
\hline 1994 & 43 & $\begin{array}{c}4.2 \\
(3.1 ; 5.6)\end{array}$ & 324 & $\begin{array}{c}31.3 \\
(2.9 ; 3.4)\end{array}$ & 349 & $\begin{array}{c}33.7 \\
(30.9 ; 36.6)\end{array}$ & 194 & $\begin{array}{c}18.7 \\
(16.5 ; 21.2)\end{array}$ & 91 & $\begin{array}{c}8.8 \\
(7.2 ; 10.7)\end{array}$ & 35 & $\begin{array}{c}3.4 \\
(2.4 ; 4.7)\end{array}$ \\
\hline 2010 & 114 & $\begin{array}{c}3.0 \\
(2.5 ; 3.6)\end{array}$ & 712 & $\begin{array}{c}18.9 \\
(17.7 ; 20.2)\end{array}$ & 1,002 & $\begin{array}{c}26.7 \\
(25.1 ; 27.9)\end{array}$ & 1,002 & $\begin{array}{c}26.7 \\
(25.3 ; 28.1)\end{array}$ & 670 & $\begin{array}{c}17.8 \\
(16.6 ; 19.1)\end{array}$ & 268 & $\begin{array}{c}7.1 \\
(6.3 ; 8.0)\end{array}$ \\
\hline \multicolumn{13}{|l|}{ Pelotas } \\
\hline 1982 & 60 & $\begin{array}{c}2.6 \\
(2.0 ; 3.3)\end{array}$ & 664 & $\begin{array}{c}28.8 \\
(27.1 ; 30.8)\end{array}$ & 888 & $\begin{array}{c}38.6 \\
(36.7 ; 40.6)\end{array}$ & 465 & $\begin{array}{c}20.2 \\
(18.9 ; 21.9)\end{array}$ & 159 & $\begin{array}{c}6.9 \\
(5.9 ; 8.0)\end{array}$ & 63 & $\begin{array}{c}2.7 \\
(2.1 ; 3.5)\end{array}$ \\
\hline 1993 & 102 & $\begin{array}{c}5.6 \\
(4.6 ; 6.7)\end{array}$ & 580 & $\begin{array}{c}31.8 \\
(29.7 ; 33.9)\end{array}$ & 627 & $\begin{array}{c}34.3 \\
(32.2 ; 36.5)\end{array}$ & 324 & $\begin{array}{c}17.7 \\
(16.1 ; 19.6)\end{array}$ & 138 & $\begin{array}{c}7.6 \\
(6.4 ; 8.9)\end{array}$ & 55 & $\begin{array}{c}3.0 \\
(2.3 ; 3.9)\end{array}$ \\
\hline 2004 & 106 & $\begin{array}{c}6.5 \\
(5.4 ; 7.7)\end{array}$ & 514 & $\begin{array}{c}31.3 \\
(29.1 ; 33.6)\end{array}$ & 508 & $\begin{array}{c}30.9 \\
(28.7 ; 33.2)\end{array}$ & 294 & $\begin{array}{c}17.9 \\
(16.1 ; 19.8)\end{array}$ & 160 & $\begin{array}{c}9.7 \\
(8.4 ; 11.3)\end{array}$ & 61 & $\begin{array}{c}3.7 \\
(2.9 ; 4.7)\end{array}$ \\
\hline 2015 & 68 & $\begin{array}{c}3.3 \\
(2.6 ; 4.2)\end{array}$ & 459 & $\begin{array}{c}22.3 \\
(20.6 ; 24.2)\end{array}$ & 572 & $\begin{array}{c}27.8 \\
(25.9 ; 29.8)\end{array}$ & & $\begin{array}{c}22.2 \\
(20.4 ; 24.0)\end{array}$ & 369 & $\begin{array}{c}17.9 \\
(16.3 ; 19.7)\end{array}$ & 132 & $\begin{array}{c}6.4 \\
(5.4 ; 7.6)\end{array}$ \\
\hline \multicolumn{13}{|l|}{ São Luís } \\
\hline 1997 & 99 & $\begin{array}{c}7.3 \\
(6.0 ; 8.8)\end{array}$ & 510 & $\begin{array}{c}37.7 \\
(35.2 ; 40.3)\end{array}$ & 474 & $\begin{array}{c}35.1 \\
(32.6 ; 37.6)\end{array}$ & 189 & $\begin{array}{c}14.0 \\
(12.2 ; 15.9)\end{array}$ & 59 & $\begin{array}{c}4.4 \\
(3.4 ; 5.6)\end{array}$ & 21 & $\begin{array}{c}1.6 \\
(1.0 ; 2.4)\end{array}$ \\
\hline 2010 & 111 & $\begin{array}{c}4.5 \\
(3.8 ; 5.4)\end{array}$ & 648 & $\begin{array}{c}26.3 \\
(24.6 ; 28.1)\end{array}$ & 811 & $\begin{array}{c}33.0 \\
(31.1 ; 34.9)\end{array}$ & 524 & $\begin{array}{c}21.3 \\
(19.7 ; 23.0)\end{array}$ & 268 & $\begin{array}{c}10.9 \\
(9.7 ; 12.2)\end{array}$ & 98 & $\begin{array}{c}4.0 \\
(3.3 ; 4.8)\end{array}$ \\
\hline Total & 751 & $\begin{array}{c}4.0 \\
(3.8 ; 4.3)\end{array}$ & 4,999 & $\begin{array}{c}26.9 \\
(26.2 ; 27.5)\end{array}$ & 6,151 & $\begin{array}{c}33.1 \\
(32.4 ; 33.7)\end{array}$ & 3,907 & $\begin{array}{c}21.0 \\
(20.4 ; 21.6)\end{array}$ & 2,043 & $\begin{array}{c}11.0 \\
(10.5 ; 11.4)\end{array}$ & 763 & $\begin{array}{c}4.1 \\
(3.8 ; 4.4)\end{array}$ \\
\hline
\end{tabular}

95\%Cl: 95\% confidence interval.

Among mothers aged 35 or older during their first childbirth a decrease of proportion was observed among the poorest income quintiles and a significant increase in the richer quintiles in the cities of Ribeirão Preto and Pelotas. In the city of São Luís, the poorer income quintiles suffer little variation between the two cohorts for the primiparous aged 15 or younger, and the proportion of mothers aged 35 or older increased in the fourth income quintile but not in the richest one (Table 5).

\section{Discussion}

Data from the Pelotas birth's cohorts show that maternal average age and schooling years increased over time. This information is also evident when comparing the data from 1978 and 2010 from Ribeirão Preto. Childbearing seems to have been postponed among the rich and higher-educated women. Primiparity among women aged over 30 years increased among the rich but remained stable for the poor. Teenage childbearing decreased until the early 2000 s followed by an increase, especially among poor women.

The rise in the proportion of women who chose to delay childbearing reflects the stage of demographic transition Brazil is going through - where a low-level fertility equilibrium has been reached. The postponement of childbearing is associated with low fertility rates, as noted when women delay their first pregnancy to older ages, also reflecting on a reduced number of children per woman 25. Other than a reduced number of children, delaying childbearing has a demographic effect in popula- 
Primiparous mothers, aged $\leq 15$ years and $\geq 35$ years, according to income quintiles in each cohort.

\begin{tabular}{|c|c|c|c|c|c|c|c|c|c|c|c|}
\hline \multirow[t]{3}{*}{ Cohorts } & \multirow[t]{3}{*}{$n$ * } & \multicolumn{10}{|c|}{ Income (quintile) } \\
\hline & & \multicolumn{2}{|c|}{ 1st (poorer) } & \multicolumn{2}{|c|}{ 2nd } & \multicolumn{2}{|c|}{$3 r d$} & \multicolumn{2}{|c|}{$4^{\text {th }}$} & \multicolumn{2}{|c|}{ 5th (richer) } \\
\hline & & $\begin{array}{l}\leq 15 \\
n(\%)\end{array}$ & $\begin{array}{l}\geq 35 \\
\text { n (\%) }\end{array}$ & $\begin{array}{l}\leq 15 \\
\mathrm{n}(\%)\end{array}$ & $\begin{array}{l}\geq 35 \\
\text { n (\%) }\end{array}$ & $\begin{array}{l}\leq 15 \\
n(\%)\end{array}$ & $\begin{array}{l}\geq 35 \\
\text { n (\%) }\end{array}$ & $\begin{array}{l}\leq 15 \\
n(\%)\end{array}$ & $\begin{array}{l}\geq 35 \\
\text { n (\%) }\end{array}$ & $\begin{array}{l}\leq 15 \\
\mathrm{n}(\%)\end{array}$ & $\begin{array}{l}\geq 35 \\
\text { n (\%) }\end{array}$ \\
\hline \multicolumn{12}{|c|}{ Ribeirão Preto } \\
\hline 1978 & 54 & $17(56.7)$ & $4(16.7)$ & $4(13.3)$ & $6(25.0)$ & $6(20.0)$ & $5(20.8)$ & $1(3.3)$ & $3(12.5)$ & $2(6.7)$ & $6(25.0)$ \\
\hline 1994 & 78 & $7(16.3)$ & $4(11.4)$ & $2(4.7)$ & $6(17.1)$ & $1(2.3)$ & 12 (34.3) & $32(74.4)$ & $11(31.4)$ & $1(2.3)$ & $2(5.7)$ \\
\hline 2010 & 382 & $40(35.1)$ & $13(4.9)$ & $24(21.1)$ & $29(10.8)$ & $14(12.3)$ & $44(16.4)$ & $4(3.5)$ & $108(40.3)$ & $32(28.1)$ & 74 (27.6) \\
\hline \multicolumn{12}{|l|}{ Pelotas } \\
\hline 1982 & 122 & $28(47.5)$ & $6(9.5)$ & $29(46.2)$ & $29(43.0)$ & - & - & $2(3.4)$ & $15(23.8)$ & - & $13(20.6)$ \\
\hline 1993 & 151 & $28(29.2)$ & $5(9.1)$ & $28(29.2)$ & $4(7.3)$ & 15 (15.6) & $7(12.7)$ & 15 (15.6) & $8(14.6)$ & $10(10.4)$ & $31(56.4)$ \\
\hline 2004 & 167 & $36(34.0)$ & $2(3.3)$ & $26(24.5)$ & $4(6.6)$ & $22(20.8)$ & $10(16.4)$ & $16(15.1)$ & $13(21.3)$ & $6(5.7)$ & $32(52.5)$ \\
\hline 2015 & 200 & $31(45.6)$ & $9(6.8)$ & $15(22.1)$ & $8(6.1)$ & $8(11.8)$ & $14(10.6)$ & $9(13.2)$ & $27(20.5)$ & $5(7.4)$ & $74(56.1)$ \\
\hline \multicolumn{12}{|l|}{ São Luís } \\
\hline 1997 & 120 & $27(27.3)$ & $1(4.8)$ & $22(22.2)$ & $1(4.8)$ & $17(17.2)$ & $3(14.3)$ & $18(18.2)$ & $3(14.3)$ & $15(15.2)$ & 13 (61.9) \\
\hline 2010 & 209 & $29(26.1)$ & $10(10.2)$ & $22(19.8)$ & $12(12.2)$ & 15 (13.5) & $20(20.4)$ & $2(1.8)$ & $44(44.9)$ & 43 (38.7) & $12(12.2)$ \\
\hline Total & 1,483 & $243(33.5)$ & $54(7.1)$ & $172(23.7)$ & $99(13.1)$ & $98(13.5)$ & $115(15.2)$ & 99 (13.6) & $232(30.7)$ & $114(15.7)$ & $257(34.0)$ \\
\hline
\end{tabular}

* Number of primiparous mothers from the lowest and highest age groups with income information for each included cohort.

Note: missing data for this analysis: Ribeirão Preto: $1978=24$; Pelotas: $1982=1 ; 1993=6$.

tions growth since there will be fewer women in the future and therefore fewer births. Also, it causes a sociological effect, because of the idea of an ideal family portrayed for future generations to follow 25. Considering that there is a known association of age advance with fertility reduction, childlessness (reaching the end of the fertility stage without giving birth) is getting more common in countries that reached a low fertility equilibrium 4 .

In Brazil, this low fertility pattern was not evenly reached among different socioeconomic groups. White women and those women with a higher level of education (4-7 years of study) were the first to postpone fertility compared to black women and those with lower education levels (0-3 years) in the years 1980s and 1990s 4.

In our sample, the proportion of primiparous mothers aged 35 years or older was higher among the richer. This is likely a reflection of the association between education and economic achievement that can result in the delaying of childbearing among higher educated women, that prioritize career fulfillment when planning to start a family 26.

Moreover, being a first-time mother when the woman is aged 35 years or older is related to a higher risk of complications due to the accumulation of risk factors. Primiparity and maternal older age are associated with the risk of developing hypertension and pre-eclampsia that can lead to preterm childbirth and complications to the infant 8,13. Considering the known risks for first-time mothers who are aged 35 years or older, this group's antenatal care can be especially directed to prevent and to control them.

Teenage childbearing is directly associated with unplanned pregnancies and it is more commonly observed among the poorest population strata, those living in rural areas, and with lower schooling years. Pregnancy and labor represent a health risk for this population of young women, being one of the main causes of death among girls aged from 15 to 19 years worldwide 27.

In this article, we observed that teenage pregnancies were rising when comparing the cohorts that date until 2004 and showed a decrease in the 2010 and 2015 cohorts, suggesting a patterns of growth followed by a decline that could be a reflection of the lack of continued investments in policies that focus in this age group when investing in women's health. Also, Brazilian economic policies that had been focusing on poverty reduction and human development [Brazil's HDI rising from 0.649 (2000) 
to 0.755 (2015)] suffered a step back in recent years with drastic political changes that could make the scenario for teenage pregnancies in years to become even worse.

Reproductive health agenda should plan actions that focus on preventing possible complications associated with primiparity in mothers aged over 35 , as well as, on younger girls under 19 years-old, in lower socioeconomic groups, aiming to reduce the vulnerability these women are placed in and the risk of unwanted pregnancies.

In Brazil, the female health agenda started being developed in the early 20th century, focusing exclusively on pregnancy and labor. These policies are characterized by not evaluating the population's health needs and establishing its goals on a general level. Since then, programs and policies have been trying to adjust to female health needs such as contraception and family planning. In 2003, the Woman's Integral Health Attention Policy was launched aiming to broadly cover female health needs. However, teenage female health is listed as one of the gaps still to be addressed 28 .

We also observed an increase in primiparous mothers with black or brown skin color, reaching up to about $30 \%$ of the mothers in the 2015 Pelotas cohort (compared to $18 \%$ in 1982) and $42 \%$ in Ribeirão Preto's 2010 cohort (compared to $30 \%$ in 1978). This could be due to how the variables were collected, with the interviewer in Pelotas 1982 and 1993, and Ribeirão Preto 1978, and self-report in Pelotas 2004 and 2015, and Ribeirão Preto 2010. Also, African ancestry consciousness has arisen over the years, possibly influencing participants' answers 29 .

The city of São Luís showed some results that did not agree with those observed in Ribeirão Preto and Pelotas (lower difference in maternal age and schooling over the studied periods, increase (and not decrease) in the proportion of primiparous living with a partner, lower proportion of mothers aged over 30 years old, smaller reduction among teenage mothers). Among the included cities, São Luís has the most disparities compared with the other included populations (about $80 \%$ of the black and brown-skinned population, seaside located, with an HDI near Pelotas' index). This could explain why the included covariates suffered lower improvements throughout the compared periods (1997 to 2010), for example, the lower increase of primiparous mothers aged 35 or over.

Regarding the study limitations, a clear disparity in the way information was collected in each cohort and especially through the years can be observed. Older cohorts tend to present greater proportions of missing information for the interviewed individuals turning the comparison within and between locations difficult to perform.

A strength of this study that should be highlighted is the high enrollment rates of all included cohorts - which are above 95\%. This increases the representativeness of the findings of the included samples over the populations they were taken from.

\section{Conclusion}

In the 40 years covered by this study, primiparous mothers' profile has changed. Women who are delivering their first child tend to be older, higher educated, and to belong to richer income groups. A rise in the proportion of women having their first child after 30 years of age was also observed. Teenage childbearing showed a decrease in the whole population, however, an increase in the proportion of primiparous teenage mothers - notably among those in lower-income groups - in the late 2000s should be understood as an awakening sign to the direct political actions to be taken in order to break this rising phenomenon. 


\section{Contributors}

S. Farias-Antunez participated in the study design, data analysis, writing and revision of the final text. V. M. F. Simões, V. C. Cardoso and M. F. Silveira contributed in the study design, data analysis and revision of the final text.

\section{Additional informations}

ORCID: Simone Farias-Antunez (0000-0002-15464217); Vanda Maria Ferreira Simões (0000-00018351-1348); Viviane Cunha Cardoso (0000-00022677-5600); Mariângela Freitas da Silveira (00000002-2861-7139).

\section{Acknowledgments}

The data collection of the included cohorts were partially financed by the Brazilian National Research Council (CNPq); São Paulo State Research Foundation (FAPESP); the Brazilian Association of Collective Health (ABRASCO); the Wellcome Trust, the World Health Organization; European Union; National Support Program for Centers of Excellence (PRONEX); Brazilian Ministry of Health; Maranhão State Research Foundation (FAPEMA); Brazilian Graduate Studies Coordinating Board (CAPES; financing code 001).

\section{References}

1. Vasconcelos AMN, Gomes MMF. Transição demográfica: a experiência brasileira. Epidemiol Serv Saúde 2012; 21:539-48.

2. Gonçalves GQ, Carvalho JAM, Wong LLR, Turra CM. A transição da fecundidade no Brasil ao longo do século XX - uma perspectiva regional. Rev Bras Estud Popul 2019; 36:e0098.

3. Tejada CA, Triaca LM, Costa FK, Hellwig F. The sociodemographic, behavioral, reproductive, and health factors associated with fertility in Brazil. PLoS One 2017; 12:e0171888.

4. Miranda-Ribeiro AG, Alexandrino R, Faria TCAB. Baixa fecundidade e adiamento do primeiro filho no Brasil. Rev Bras Estud Popul 2019; 36:e0080.

5. Centers for Disease Control and Prevention. National health statistics reports: intended and unintended births in the United States: 19822010. Atlanta: Centers for Disease Control and Prevention; 2012.

6. Rede Interagencial de Informações para Saúde. Demografia e saúde: contribuição para análise de situação e tendências. Brasília: Organização Pan-Americana da Saúde; 2009.

7. Duckitt K, Harrington D. Risk factors for preeclampsia at antenatal booking: systematic review of controlled studies. BMJ 2005; 330:565.

8. Hashim N, Naqvi S, Khanam M, Jafry HF. Primiparity as an intrapartum obstetric risk factor. J Pak Med Assoc 2012; 62:694-8.

9. Nystedt A, Hildingsson I. Diverse definitions of prolonged labour and its consequences with sometimes subsequent inappropriate treatment. BMC Pregnancy Childbirth 2014; $14: 233$

10. Guan P, Tang F, Sun G, Ren W. Prediction of emergency cesarean section by measurable maternal and fetal characteristics. J Investig Med 2020; 68:799-806.

11. American College of Obstetricians and Gynecologists; Committee on Gynecologic Practice; Committee of the American Society for Reproductive Medicine. Female age-related fertility decline. Obstet Gynecol 2014; 123:71921.

12. Cavazos-Rehg PA, Krauss MJ, Spitznagel EL, Bommarito K, Madden T, Olsen MA, et al. Maternal age and risk of labor and delivery complications. Matern Child Health J 2015; 19:1202-11.

13. Molina-García L, Hidalgo-Ruiz M, Arredondo-López B, Colomino-Ceprián S, DelgadoRodríguez M, Martínez-Galiano JM. Maternal age and pregnancy, childbirth and the puerperium: obstetric results. J Clin Med 2019; 8:672.

14. Kahveci B, Melekoglu R, Evruke IC, Cetin C. The effect of advanced maternal age on perinatal outcomes in nulliparous singleton pregnancies. BMC Pregnancy Childbirth 2018; $18: 343$. 
15. Barbieri MA, Gomes UA, Borros Filho AA, Bettiol H, Almeida LEA, Silva AAM. Saúde perinatal em Ribeirão Preto, SP, Brasil: a questão do método. Cad Saúde Pública 1989; 5:376-87.

16. Bettiol H, Barbieri MA, Gomes UA, Andrea M, Goldani MZ, Ribeiro ERO. Saúde perinatal: metodologia e características da população estudada. Rev Saúde Pública 1998; 32:18-28.

17. Pimenta JRR, Grandi C, Aragon DC, Cardoso VC. Comparison of birth weight, length, and head circumference between the BRISA-RP and Intergrowth-21st cohorts. J Pediatr (Rio J.) 2020; 96:511-9.

18. Hallal PC, Bertoldi AD, Domingues MR, Silveira MF, Demarco FF, Silva ICM, et al. Cohort profile: the 2015 Pelotas (Brazil) birth cohort study. Int J Epidemiol 2018; 47:10481048h.

19. Santos IS, Barros AJ, Matijasevich A, Domingues MR, Barros FC, Victora CG. Cohort profile: the 2004 Pelotas (Brazil) birth cohort study. Int J Epidemiol 2010; 40:1461-8.

20. Victora CG, Barros FC. Cohort profile: the 1982 Pelotas (Brazil) birth cohort study. Int J Epidemiol 2005; 35:237-42.

21. Victora CG, Hallal PC, Araújo CL, Menezes AM, Wells JC, Barros FC. Cohort profile: the 1993 Pelotas (Brazil) birth cohort study. Int J Epidemiol 2007; 37:704-9.

22. Silva AAM, Batista RFL, Simões VMF, Thomaz EBAF, Ribeiro CCC, Lamy Filho F, et al. Changes in perinatal health in two birth cohorts (1997/1998 and 2010) in São Luís, Maranhão State, Brazil. Cad Saúde Pública 2015; 31:1437-50.
23. Silva AAM, Coimbra LC, Silva RA, Alves MTSSB, Lamy Filho F, Lamy ZC, et al. Perinatal health and mother-child health care in the municipality of São Luís, Maranhão State, Brazil. Cad Saúde Pública 2001; 17:1412-23.

24. Goldstein JR, Sobotka T, Jasilioniene A. The end of lowest-low fertility? Popul Dev Rev 2009; 35:663-700.

25. Lutz W, Skirbekk V, Testa MR. The low-fertility trap hypothesis: forces that may lead to further postponement and fewer births in Europe. Vienna Yearb Popul Res 2006; 4:167-92.

26. Miranda-Ribeiro A, Garcia RA. Transition or transitions? Analyzing the fertility decline in Brazil in the light of educational levels. Revista Latinoamericana de Población 2015; 13:91106.

27. World Health Organization. Causes of death among adolescentes. https://www.who.int/ maternal_child_adolescent/data/causesdeath-adolescents/en/\#: : :text=Estimated\%20 top\%205\%20causes\%20of,self\%2Dharm\%20 and $\% 20$ road\%20injury (accessed on Mar/2020).

28. Ministério da Saúde. Política Nacional de Atenção Integral à Saúde da Mulher Princípios e Diretrizes. Brasília: Ministério da Saúde; 2004.

29. Soares S. A demografia da cor: a composição da população brasileira de 1890 a 2007. In: Theodoro M, Soares S, Osorio RG, Jaccoud LB, organizadores. As políticas públicas e a desigualdade racial no Brasil: 120 anos após a abolição. Brasília: Instituto de Pesquisa Econômica Aplicada; 2008. p. 97-118. 


\section{Resumo}

A redução na taxa de fertilidade é um fenômeno observado na transição demográfica. As mudanças demográficas na fertilidade feminina criam a necessidade de ajustes nos serviços de saúde em termos de saúde da mulher e planejamento familiar. Assim, o estudo buscou realizar uma análise descritiva, traçando o perfil sociodemográfico de mães primíparas em nove coortes de nascimentos, de três cidades em estados diferentes do Brasil. Foram aplicados questionários padronizados para avaliar as características reprodutivas e covariáveis. As mães primíparas foram definidas como mulheres cujos filhos incluídos nas coortes de nascimentos eram os seus primogênitos. A descrição da amostra foi realizada com a análise de variância (variáveis contínuas) e qui-quadrado (variáveis categóricas). Um total de 44.615 mulheres foram incluidas nas análises, e 41,8\% (IC95\%: 41,3; 42,2) foram categorizadas como primíparas. As taxas de primiparidade foram mais baixas em Ribeirão Preto (São Paulo) em 1978 (32\%; IC95\%: 30, 9; 33,1), e as mais altas foram nas coortes mais recentes, atingindo 50\% das participantes (São Luís - Maranhão, 2010: 47,2\%; IC95\%: 45, 8; 48,6; Ribeirão Preto, 2010: 50,2\%; IC95\%: 49,1; 51,4); Pelotas (Rio Grande do Sul) 2015: 49,4\% (IC95\%: 47,9; 50,9). A idade e escolaridade das primíparas aumentaram ao longo dos anos em todas as coortes. A idade materna no primeiro parto mostrou perfil semelhante nas três cidades. Houve um aumento na proporção de primíparas mais velhas, com maior escolaridade e pertencentes aos estratos econômicos mais altos. Além disso, a proporção de mães adolescentes (até 15 anos de idade) aumentou até o início da década de 2000 e começou a diminuir em torno dos anos 2010, especialmente entre mulheres nos grupos de menor renda.

Paridade; Gravidez; Gravidez na Adolescência; Fatores Socioeconômicos

\section{Resumen}

La reducción de la fertilidad es un fenómeno observado en la transición demográfica. Los cambios demográficos observados en la fertilidad femenina representan la necesidad de un ajuste en los servicios de salud, en términos de salud femenina y asistencia a la planificación familiar. Teniendo esto en consideración, este estudio tuvo como objetivo realizar un análisis descriptivo, mediante el seguimiento del perfil sociodemográfico de las madres primíparas, que pertenecen a nueve cohortes de brasileñas nacimiento, en tres ciudades de diferentes estados. Se aplicaron cuestionarios estandarizados para evaluar las características reproductivas y covariables. Las madres primíparas fueron definidas como mujeres cuyos hijos incluidos en las cohortes de nacimiento eran sus primogénitos. La descripción de la muestra se realizó usando un análisis de variancia (variables continuas) y chi-cuadrado (variables categóricas). Un total de 44.615 mujeres estuvieron incluidas en el análisis y un 41,8\% (IC95\%: 41,3; 42,2) fueron categorizadas como primíparas. La tasas de primiparidad fueron las más bajas en Ribeirão Preto (Estado de São Paulo) 1978 (32\%; 95\%CI: 30,9; 33,1) y las más altas en las cohortes más recientes, alcanzando hasta a un 50\% de los participantes (São Luís - Estado de Maranhão 2010: 47,2\%; IC95\%: 45, 8; 48,6; Ribeirão Preto 2010: 50,2\%; IC95\%: 49,1; 51,4); Pelotas (Estado de Rio Grande do Sul) 2015: 49,4\% (IC95\%: 47,9; 50,9). La edad de las madres primíparas y escolaridad se incrementó a lo largo de los años en todas las cohortes. La edad maternal en el momento del nacimiento del primer hijo se comportó de forma similar en las tres ciudades estudiadas. Hubo un incremento en la proporción de las madres por primera vez, que eran más viejas, con más formación educativa, y pertenecientes a los grupos con ingresos más altos. Asimismo, la proporción de las madres adolescentes (15 años o más jóvenes) se incrementó hasta principios del año 2000 y empezó a decrecer a partir del año 2010, especialmente entre mujeres en los grupos con los ingresos más bajos.

Paridad; Embarazo; Embarazo en Adolescencia; Factores Socioeconómicos

Submitted on 25/Mar/2020

Final version resubmitted on $06 /$ Oct $/ 2020$

Approved on 09/Oct/2020 